FOCAL PROBLEMS IN GEOGRAPHY SERIES

\title{
TRANSPORT FOR THE SPACE ECONOMY
}




\section{Focal Problems in Geography Series}

\section{Published}

DAVID GRIGG: The Harsh Lands

ALAN HAY: Transport for the Space Economy

Titles in preparation include

MICHAEL F. THOMAS: Tropical Geomorphology

JOHN O. BAILEY: Urban Climatology

BARRY J. GARNER: Linkages within Cities

J. T. COPPOCK and B. S. DUFFIELD: Recreation in the Countryside 


\title{
Transport for the Space Economy a geographical study
}

\author{
ALAN HAY
}

Department of Geography, University of Sheffield 
(C) Alan M. Hay 1973

All rights reserved. No part of this publication may be reproduced or transmitted, in any form or by any means, without permission

First published 1973 by THE MACMILLAN PRESS LTD London and Basingstoke Associated companies in New York Dublin Melbourne Johannesburg and Madras

ISBN 978-0-333-11419-3 ISBN 978-1-349-86191-0 (eBook) DOI 10.1007/978-1-349-86191-0

The paperback edition of this book is sold subject to the condition that it shall not, by way of trade or otherwise, be lent, resold, hired out, or otherwise circulated without the publisher's prior consent in any form of binding or cover other than that in which it is published and without a similar condition including this condition being imposed on the subsequent purchaser. 
For A.M.H., E.E.H. and P.A.H. 


\section{Contents}

List of Figures viii

List of Tables $\quad \mathrm{x}$

Preface $\quad$ xi

1 Introduction 1

2 Transport Demand 6

3 Elementary Description of Transport Networks 34

4 Topological Approaches to Network Form 46

5 The Explanation of Network Form 62

6 Technical and Economic Properties of Transport Networks 83

7 Vehicle Supply 106

8 Patterns of Transport Flow 117

9 The Explanation of Flow Systems 126

10 The Intermodal Allocation of Flows 145

11 Decision Making and Government Policy in the Transport Sector

Notes and References 166

$\begin{array}{ll}\text { Index } & 187\end{array}$ 


\section{List of Figures}

1.1 Elements in the spatial analysis of transport problems 2

2.1 Elementary maps of transport demand 7

2.2 A simple interpretation of interregional transport demand 14

2.3 A simple interpretation of interregional transport demand in a three-region case

2.4 The effect of delay on transport demand 27

2.5 Secular trend in demand and indivisibilities in supply 31

3.1 Some elementary network properties 36

3.2 Access distance in three regular networks 37

4.1 The interpretation of a transport network as a graph $\quad 47$

4.2 The diameter as a measure of graph form 48

4.3 The associated number of vertices in a graph 49

4.4 Two graph interpretations of a three-way junction 50

4.5 The ideal networks examined by Werner's seminar (after Werner) 51

4.6 Associated number distribution for ideal networks (after Werner)

4.7 The primary and secondary road networks of Ghana: beta index, 1910-59 (after Yeates)

4.8 The interpretation of a graph as a matrix

5.1 Rail networks on the border between Canada and the United States

5.2 Negative and positive deviations in route alignment 66

$\begin{array}{lll}\text { 5.3 The least cost route problem } & 67\end{array}$

5.4 Two 'optimal' networks 69

5.5 An exploratory route building sequence $\quad 70$

5.6 A game type route location problem 72

5.7 The results of a network simulation (after Kansky) 79

5.8 The sequence of network development (after Taaffe, Morrill and Gould)

6.1 The max-flow min-cut problem (after Garrison and Marble)

6.2 Traffic speed and density 
List of Figures $\quad$ ix

6.3 Traffic density and route capacity (after Gerondeau) 88

6.4 Traffic flow and maintenance costs (after Soberman) 90

6.5 Costs of network provision 98

6.6 Costs of operation on the network 101

6.7 Tariffs 104

8.1 Salience scores for interregional trade in Nigeria (after Smith) 120

9.1 Comparative advantage and the flow of commodities 134

9.2 Interregional trading equilibrium 136

10.1 Determinants of intermodal allocation: freight traffic $\quad 146$

10.2 Determinants of intermodal allocation: passenger traffic 151 


\section{List of Tables}

2.1 The matrix presentation of transport demand

2.2 Estimated proportion of road vehicles in the United Kingdom idle during each quarter of 1962

2.3 The regularity of consignment by industrial establishments 24

2.4 Annual variations in the cocoa tonnage to be transported in Western Nigeria, 1953-4

2.5 Variations in Nigerian port traffic, 1955-66 26

3.1 Examples of access point density and accessibility $\quad 40$

3.2 Nearest neighbour tests on the spacing of Wisconsin airports

4.1 The railway networks of thirteen countries ranked by graph theoretic measures

4.2 The correlation coefficients between graph theoretic measures applied to the rail and road networks of twenty-five countries

4.3 Powering procedures applied to the connectivity matrix in figure 4.8

4.4 The means and variances of the Shimbel index applied to eight ideal networks

5.1 Pay-off table for the route location game in figure 5.6

5.2 Railway location game: pay-off table for railway I when allowing II to act first

5.3 Railway location game: range of strategies available to railway I

5.4 Summary of strategies for railway I

8.1 Components of commodity flow systems

9.1 Optimal flow patterns determined by linear programming 138

10.1 Reasons for running own vehicle fleet in preference to using rail transport 


\section{Preface}

This book attempts to bring order to a diverse field, and in so doing to fill a gap of which I have been aware as student, research worker and teacher. Although the book draws its inspiration from geography - particularly the recent literature on locational analysis-this limits neither the literature surveyed nor I hope the range of people who will find the discussion of value. With a wider readership in mind I have attempted to write in such a fashion that even those who have little geographical or statistical training will be able to grasp the main arguments, but some introductory reading for them is listed at the beginning of the bibliographical notes.

In writing I have been constantly reminded of the debt I owe to teachers, colleagues and students. Among the first, three should be mentioned by name: Mr F. G. Self of Norwich School, Mr A. A. L. Caesar of St Catharine's College, Cambridge, and Professor Peter Haggett, then of Cambridge and now of Bristol. Each one of them has taught me much; this book is a poor reflection of the standards which they set. Among those I count as colleagues I would like to mention three also: Bob Smith whose help on many topics has clarified my thinking, my brother Donald who has always been a trenchant critic of my ideas, and Michael Chisholm who, as the publisher's adviser, persuaded me to write, to keep on writing and to improve my early drafts. Many other colleagues at Ibadan, Leicester, Madison and Sheffield have helped me, as have many unknown to me personally but whose work I have quoted in the following pages: if this is too brief an acknowledgement I ask their forgiveness. My students at Leicester listened to early versions of this book; their views, their questions, their incomprehension and even their examination scripts have all contributed to this final version. None of these people bears any responsibility for my errors and omissions.

Drafts of the book were typed by Jean Smith and Monica Long. I am grateful to both these people.

I would like to acknowledge the advice of Professor Ullman of the 
University of Washington and Dr Fullerton of the University of Newcastle upon Tyne, both of whom read the final draft and made valuable suggestions.

Finally I owe a debt to the members of my family: and to three of them this book is dedicated.

ALAN HAY

Sheffield, 1973 